\title{
Analisis Faktor Orang Tua Menyekolahkan Anak pada Sekolah Dasar Berbasis Islam di Kota Malang
}

\author{
Nova Nur Khasanah*, Imron Arifin, Ahmad Nurabadi \\ Universitas Negeri Malang, Jl. Semarang No. 5 Malang, Jawa Timur, Indonesia \\ *Penulis korespondensi, Surel: novanurkhasanah04@gmail.com
}

Paper received: 7-6-2021; revised: 21-6-2021; accepted: 28-6-2021

\begin{abstract}
This study intends to explore the factors behind the choice of parents to send their children to Islamic based elementary schools in Malang city. The sample consisted of 162 class I parents using cluster/area sampling and proportional sampling. The data collection tool is a closed questionnaire. While data analysis uses SPSS 24.00 for windows. The results of the study obtained factors that influence the choice of parents to send their children to Islamic based elementary schools in Malang, namely religious factors, character education, school quality, potential development, and service.
\end{abstract}

Keywords: choice factors; choice of parents; elementary school based on Islam

\begin{abstract}
Abstrak
Penelitian ini bermaksud untuk menggali faktor yang melatarbelakangi pilihan orangtua menyekolahkan anak pada SD berbasis Islam di Kota Malang. Sampel terdiri atas 162 orangtua kelas I dengan menggunakan cluster/area sampling dan proportional sampling. Alat pengumpul data adalah angket tertutup. Sedangkan analisis data menggunakan SPSS 24.00 for windows. Hasil penelitian diperoleh faktor yang mempengaruhi pilihan orangtua menyekolahkan anak pada SD berbasis Islam di Kota Malang yaitu faktor religi, pendidikan karakter, mutu sekolah, pengembangan potensi, dan pelayanan.
\end{abstract}

Kata kunci: faktor pilihan; pilihan orang tua; SD berbasis Islam

\section{Pendahuluan}

Anak merupakan karunia dari Allah SWT yang menjadi anugerah terindah sekaligus amanah bagi setiap orangtua. Anak ialah generasi yang memberi warna pada masa kini serta sangat diharapkan untuk dapat mengusung kemajuan pada masa yang akan datang. Berdasarkan Undang-Undang Nomor 23 Tahun 2002 tentang Perlindungan Anak, anak adalah manusia yang berumur di bawah 18 tahun, yang dalam hal ini termasuk janin yang masih berada dalam kandungan seorang ibu. Anak juga merupakan aset bagi sebuah bangsa. Masa depan bangsa tentu sangat bergantung pada anak, dimana ia bertindak sebagai generasi penerus cita-cita perjuangan bangsa. Dengan demikian, anak memiliki peranan yang strategis dalam pembangunan sebuah bangsa.

Namun demikian, belakangan ini di media massa Tempo banyak diberitakan mengenai arus pergaulan anak yang semakin bebas, moral yang semakin merosot, dan juga nilai-nilai agama yang semakin pudar. Komisi Perlindungan Anak Indonesia (KPAI) memperoleh data sebanyak $84 \%$ peserta didik di Indonesia pernah menjadi korban tindak kekerasan saat berada disekolah (Tempo, 2 Mei 2018). Secara lebih lanjut media Tempo menerangkan bahwa $40 \%$ peserta didik yang berumur 13-15 tahun melaporkan bahwa ia pernah menjadi korban tindak kekerasan fisik yang dilakukan oleh temannya sendiri. Di sisi lain, $50 \%$ peserta didik juga melaporkan bahwa ia pernah menjadi korban bullying saat berada di sekolah. Maraknya 
fenomena tersebut tentu menimbulkan kekhawatiran orangtua terhadap terbawanya sang buah hati pada arus tersebut. Untuk itu, maka diperlukan suatu upaya cerdas untuk mencegah sekaligus menanggulangi anak dari hal-hal yang negatif dan menjerumuskan. Upaya yang paling tepat untuk mencegah dan menanggulangi ialah melalui ranah pendidikan.

Setiap orangtua memiliki peran yang sangat penting dan berpengaruh pada pendidikan anaknya. Kecenderungan orangtua dalam memilih institusi sekolah dasar bagi anak bukannya tidak memiliki alasan yang kuat, akan tetapi pasti didasari oleh motivasi atau keinginan supaya anaknya kelak memiliki bekal yang memadai dalam menjalani hidup. Karena pendidikan yang menyeluruh sudah semestinya mempersiapkan anak untuk hidup baik di dunia maupun akhirat nanti (Sahroni, 2015). Tidak hanya aspek akademiknya saja, tetapi aspek spiritual dan mental juga harus dikembangkan. Dengan demikian, maka orangtua sangat berperan dalam mengarahkan, memilihkan dan memutuskan pendidikan dasar yang akan ditempuh oleh anaknya.

Pendidikan dasar memiliki posisi yang strategis dalam penyelenggaraan pendidikan di Indonesia. Pendidikan dasar tentu menjadi investasi jangka panjang untuk masa depan setiap anak. Hal ini dikarenakan jenjang ini menjadi langkah pertama serta menjadi pondasi awal atau institusi pendidikan yang mendasari anak sebagai modal untuk melanjutkan jenjang-jenjang pendidikan berikutnya yang lebih tinggi. Pendidikan dasar bertujuan untuk menanamkan pengetahuan (kognitif), sikap (afektif), dan keterampilan (psikomotorik) yang mendasar bagi anak yang dapat dikembangkan secara terus menerus dalam rangka meningkatkan kualitas diri (Kepala Bidang SD Dinas Pendidikan Kabupaten Bekasi, 2015). Salah satu bentuk pendidikan dasar ialah Sekolah Dasar (SD). Jenjang SD memiliki kesetaraan dengan jenjang MI (Madrasah Ibtidaiyah). Namun, pola manajerial SD dinilai lebih baik dan cakupan keilmuan SD lebih luas jika dibandingkan dengan MI (Hura, 2013). Mutu lulusan madrasah juga lebih rendah dari sekolah umum, selain itu posisi eksternal juga belum menunjang madrasah secara optimal, seperti pendanaan yang tidak memadai, rendahnya kualitas perencanaan pendidikan yang disusun, adanya pendidik dan tenaga kependidikan yang tidak profesional, kurangnya sumber daya administratif, dan lain sebagainya (Zazin, 2017).

Institusi pendidikan yang mampu memenuhi harapan umat Islam adalah sekolah yang secara holistik bernafaskan Islam. Vitasari (2017) menyebutkan bahwa sekarang ini begitu banyak orangtua yang memiliki motivasi untuk menyekolahkan anaknya ke sekolah dasar berbasis Islam. Sekolah dasar berbasis Islam merupakan satuan pendidikan formal yang melaksanakan pendidikan umum pada jenjang pendidikan dasar yang berdiri dengan berlandaskan pada nilai dan norma agama Islam serta selalu berusaha untuk mengembangkan ajaran-ajaran Islam pada seluruh komponennya (Qomar, 2015). Konsep, visi, misi, tujuan sekolah, kurikulum, aktivitas, metodologi, proses kegiatan belajar mengajar, sumber daya manusia yang meliputi pendidik dan tenaga pendidik, semuanya bersumber pada ajaran dan nilai-nilai Agama Islam. Qomar juga menjelaskan bahwasanya sekolah dasar yang berbasis Islam tersebut meliputi sekolah-sekolah yang menggunakan identitas Islam, menggunakan nama-nama organisasi Islam, menggunakan nama tokoh-tokoh Islam, dan sekolah-sekolah yang menggunakan identitas bahasa Arab.

SD berbasis Islam bertindak sebagai wahana pendidikan yang menyelenggarakan pendidikan umum sekaligus pendidikan di bidang agama. Para orangtua tentu memiliki keinginan untuk menanamkan nilai dan ajaran agama Islam pada anak sejak dini, sebab tujuh 
tahun kedua usia anak (kelas I-VI) adalah titik awal yang strategis dalam mencetak pondasi agama pada diri anak (Ulul Albab School, 2016). Nilai-nilai agama bertindak sebagai faktor yang utama dan menjadi daya pikat yang tinggi bagi para orangtua murid sebagai stakeholders, sebagaimana yang diungkapkan oleh Sholiha (2018) selaku narasumber yang diwawancarai oleh peneliti pada 3 Februari 2018. Beliau mengungkapkan alasan menyekolahkan anaknya pada salah satu SD berbasis Islam di Kota Malang tidak lain karena porsi Agama Islam yang diberikan oleh sekolah cukup memadai. Beliau berkeinginan putrinya kelak menjadi anak yang sholeh dan sholihah, mempunyai integritas diniyah yang tinggi, ahli ibadah dan berakhlakul karimah. Tak hanya itu, ternyata fasilitas sekolah yang diberikan pun cukup memadai, kedisiplinan yang diajarkan juga sangat baik terutama disiplin waktu, serta pelajaran agama dan pelajaran umum diberikan dengan porsi yang seimbang. Beliau menambahkan seandainya anak di rumah tidak mengaji pada suatu TPQ (Taman Pendidikan Al-Qur'an), anak pun tidak akan kekurangan ilmu agama karena telah diajarkan secara lengkap dan menyeluruh di sekolah.

Di Kota Malang, pada setiap tahunnya peminat SD berbasis Islam semakin meningkat. Fenomena tersebut dapat dilihat dalam kurun 4 tahun terakhir ini, dimana jumlah orangtua yang berminat untuk menyekolahkan anak ke SD berbasis Islam selalu mengalami peningkatan yang cukup tinggi apabila dibandingkan dengan jumlah orangtua peminat SD non berbasis Islam. Hal ini sesuai data yang disajikan oleh bidang pembinaan SD Dinas Pendidikan Kota Malang (2017) bahwasanya pada tahun ajaran 2014/2015 peminat SD berbasis Islam di Kota Malang berjumlah 1.646 orangtua, tahun ajaran 2015/2016 berjumlah 1.708 orangtua, tahun ajaran 2016/2017 berjumlah 1.860 orangtua, dan tahun ajaran 2017/2018 berjumlah 1.967 orangtua. Sedangkan jumlah orangtua peminat SD non berbasis Islam pada tahun ajaran 2014/2015 berjumlah 11.607, tahun ajaran 2015/2016 berjumlah 11.394, tahun ajaran 2016/2017 berjumlah 11.258, dan tahun ajaran 2017/2018 berjumlah 11.107. Dengan demikian, peneliti berkeinginan untuk melakukan penelitian mengenai faktor-faktor yang menjadi pilihan orangtua dalam menyekolahkan anak pada SD berbasis Islam di Kota Malang, faktor dominan yang menjadi pilihan orangtua dalam menyekolahkan anak pada SD berbasis Islam di Kota Malang, dan kontribusi masing-masing faktor yang menjadi pilihan orangtua dalam menyekolahkan anak pada SD berbasis Islam di Kota Malang.

\section{Metode}

Dalam penelitian ini peneliti menggunakan pendekatan kuantitatif, sedangkan desain penelitiannya menggunakan metode eksploratif-deskriptif. Penelitian ini dilakukan di SD berbasis Islam di Kota Malang. Apapun yang hendak ditetapkan, dipelajari, dan diteliti oleh peneliti hingga diperoleh suatu informasi mengenai hal tersebut dan selanjutnya disimpulkan disebut variabel (Sugiyono, 2017). Variabel yang digunakan pada penelitian ini hanya satu, yakni faktor pilihan orangtua menyekolahkan anak pada SD berbasis Islam di Kota Malang. Sedangkan sub variabel pada penelitian ini, peneliti menggunakan teori harapan dari Vroom tahun 1964. Teori harapan itu meliputi harapan/expectancy, pertautan/instrumentality, dan nilai/valence (Vroom dalam Hubeis, 2013). Metode penelitian eksploratif digunakan untuk menemukan faktor baru yang menjadi pilihan orangtua menyekolahkan anak pada SD berbasis Islam di Kota Selanjutnya metode penelitian deskriptif digunakan memberikan penjelasan secara mendalam mengenai faktor-faktor tersebut.

Semua orangtua siswa kelas I SD berbasis Islam di Kota Malang bertindak sebagai populasi penelitian, dimana berjumlah 1.966 orang dari total 38 sekolah. Teknik pengambilan 
sampel yang digunakan adalah area/cluster sampling dan proportional sampling. Jumlah sampel yang digunakan sebagai sampel penelitian adalah 162 orangtua kelas I dari 9 SD berbasis Islam di Kota Malang. Sembilan sekolah tersebut adalah SD IT Ahmad Yani, SDI Klojen Kidul, SDI Plus Al-Azhar, SDI Baitul Makmur, SD NU Hasyim Asy'ari, SD Wahid Hasyim, SD Aisyiyah, SDS Islam Al-Umm, dan SDI Assalam.

Alat pengumpul data yang digunakan pada penelitian ini adalah angket. Angket ialah sejumlah pernyataan tertulis yang berfungsi untuk mendapatkan informasi dari responden mengenai hal-hal yang ingin diteliti oleh peneliti (Arikunto, 2006). Jenis angket yang digunakan pada penelitian ini adalah angket tertutup karena alternatif jawaban yang tersedia pada daftar pernyataan telah disediakan oleh peneliti. Sehingga responden hanya tinggal membubuhkan tanda $\sqrt{ }$ (cek) pada alternatif jawaban yang dirasa paling sesuai dengan pendiriannya. Selanjutnya peneliti menggunakan skala likert sebagai skala pengukurannya serta analisis faktor eksploratori dan analisis deskriptif sebagai teknik analisis datanya.

\section{Hasil dan Pembahasan}

\subsection{Hasil}

Hasil dari penelitian ini diperoleh bahwa ada lima faktor yang menjadi pilihan orangtua menyekolahkan anak pada SD berbasis Islam di Kota Malang. Secara berurutan lima faktor baru yang ditemukan dan diberi nama baru ialah faktor religi dengan nilai variansi sebesar $17,597 \%$, pendidikan karakter dengan nilai variansi sebesar 14,493 \%, mutu sekolah dengan nilai variansi sebesar $11,651 \%$, pengembangan potensi dengan nilai variansi sebesar 9,043\%, dan pelayanan dengan nilai variansi $6,497 \%$. Faktor yang paling dominan dalam pilihan orangtua menyekolahkan anak pada SD berbasis Islam di Kota Malang adalah faktor religi karena memiliki tingkat variansi yang tinggi apabila dibandingkan dengan faktor yang lainnya, yakni 17,597 \%. Tingkat kontribusi untuk masing-masing faktor yang menjadi pilihan orangtua menyekolahkan anak pada SD berbasis Islam di Kota Malang yaitu faktor religi memiliki kontribusi sangat tinggi, faktor pendidikan karakter memiliki kontribusi sedang, faktor mutu sekolah memiliki kontribusi tinggi, faktor pengembangan potensi memiliki kontribusi sedang, serta faktor pelayanan memiliki kontribusi sangat tinggi.

\subsection{Pembahasan}

Kelompok faktor religi diwakili oleh 24 butir pernyataan dan memiliki nilai eigenvalue sebesar $17,597 \%$. Faktor religi memiliki kontribusi sangat tinggi terhadap pilihan orangtua dalam menyekolahkan anak pada SD berbasis Islam di Kota Malang. Hal ini dapat diketahui dari persentase yang dimiliki yakni sebesar $57 \%$ yang termasuk dalam kategori sangat tinggi dalam kriteria kelas intervalnya. Faktor ini berhubungan dengan pembentukan pribadi anak yang islami dan taat pada ajaran agama agar anak dapat hidup selamat di dunia dan akhirat. Religi memiliki makna yang berarti agama. Agama menurut Kamus Besar Bahasa Indonesia adalah sistem yang mengatur keimanan (kepercayaan) dan peribadatan kepada Tuhan Yang Maha Kuasa yang dapat disebut hablum minallah serta tata kaidah yang berkaitan dengan pergaulan manusia dan manusia yang dapat disebut hablum minannas serta perilaku dengan lingkungannya yang dapat disebut hablum minal'alam. Pendidikan agama memiliki peranan yang sangat penting dalam membentuk kepribadian anak. Melalui porsi pendidikan agama 
yang cukup, diharapkan akan menumbuhkan pemahaman dan kesadaran yang tepat pada setiap anak mengenai peran, tugas, dan tanggung jawab sebagai hamba Allah (Revaldi, 2010).

Faktor yang kedua adalah kelompok faktor pendidikan karakter yang diwakili oleh 19 butir pernyataan dan memiliki nilai eigenvalue sebesar 14,493 \%. Faktor pendidikan karakter memiliki kontribusi sedang terhadap pilihan orangtua dalam menyekolahkan anak pada SD berbasis Islam di Kota Malang. Hal ini dapat diketahui dari persentase yang dimiliki yakni sebesar $43 \%$ yang termasuk dalam kategori sedang dalam kriteria kelas intervalnya. Faktor ini berhubungan dengan harapan orangtua mengenai pembentukan karakter anak ketika disekolahkan di SD berbasis Islam sehingga anak tumbuh berkembang menjadi insan kamil yang berkarakter dan berbudi pekerti luhur. Pendidikan karakter menurut Wibowo (2013) merupakan sistem pendidikan yang menyelenggarakan dan menciptakan nilai-nilai karakter luhur pada seluruh anak didiknya, sehingga mereka mempunyai dan mempraktikan pada kehidupan sehari-harinya, baik dalam lingkup keluarga, masyarakat, terlebih pada lingkup negara.

Selanjutnya faktor yang ketiga yakni kelompok faktor mtu sekolah yang diwakili oleh 16 butir pernyataan dan memiliki nilai eigenvalue sebesar 11,651 \%. Faktor mutu sekolah memiliki kontribusi tinggi terhadap pilihan orangtua dalam menyekolahkan anak pada SD berbasis Islam di Kota Malang. Hal ini dapat diketahui dari persentase yang dimiliki yakni sebesar $39 \%$ yang termasuk dalam kategori tinggi dalam kriteria kelas intervalnya. Faktor ini berhubungan dengan mutu atau kualitas satuan pendidikan yang menjadikan sekolah bersangkutan menjadi pilihan orangtua dalam menyekolahkan anak pada SD berbasis Islam. Mutu sekolah mencerminkan sejauh mana para siswa memperoleh kepuasan atas pelayanan pendidikan serta pelayanan pembelajaran yang berkualitas dan sesuai dengan standar atau bahkan melebihi standar yang ditetapkan (Triatna, 2016). Organisasi pendidikan bermutu adalah organisasi yang dapat memenuhi kebutuhan para stakeholder-nya. Mutu sekolah dipengaruhi oleh kemampuan dalam mengelola pegawai, peserta didik, proses pembelajaran, sarana, keuangan dan hubungan dengan masyarakat, sedangkan standar mutu pendidikan adalah masukan/input, pemrosesan/processing, keluaran/output, dan hasil/outcome (Yakub dan Hisbanarto, 2014).

Faktor yang keempat adalah kelompok faktor pengembangan potensi yang diwakili oleh 9 butir pernyataan dan memiliki nilai eigenvalue sebesar 9,043 \%. Faktor pengembangan potensi memiliki kontribusi sedang terhadap pilihan orangtua dalam menyekolahkan anak pada SD berbasis Islam di Kota Malang. Hal ini dapat diketahui dari persentase yang dimiliki yakni sebesar $48 \%$ yang termasuk dalam kategori sedang dalam kriteria kelas intervalnya. Faktor ini berhubungan dengan harapan orangtua dalam hal pengembangan kemampuan, potensi, hingga bakat yang dimiliki anak ketika menyekolahkan anak pada SD berbasis Islam di Kota Malang. Prihadhi (2004) mengemukakan bahwa potensi merupakan kemampuan atau kekuatan dasar seseorang yang masih terpendam dan masih belum diolah dan dimanfaatkan secara maksimal. Potensi tersebut dapat berwujud karakter, bakat, minat, fisik, kecerdasan, dan nilai lainnya yang terkandung dalam diri seorang anak yang belum dikembangkan secara optimal.

Serta faktor yang kelima ialah kelompok faktor pelayanan yang diwakili oleh 7 butir pernyataan dan memiliki nilai eigenvalue sebesar 6,497 \%. Faktor pelayanan memiliki kontribusi sangat tinggi terhadap pilihan orangtua dalam menyekolahkan anak pada SD 
berbasis Islam di Kota Malang. Hal ini dapat diketahui dari persentase yang dimiliki yakni sebesar $54 \%$ yang termasuk dalam kategori sangat tinggi dalam kriteria kelas intervalnya. Faktor ini berhubungan dengan pelayanan yang diberikan oleh pihak sekolah kepada wali murid atau orangtua sebagai pelanggan atau pengguna jasa sehingga mereka merasa puas, percaya, dan senang. Pelayanan ialah perbuatan yang ditawarkan oleh suatu pihak kepada pihak lainnya dimana bersifat tidak kasat mata dan tidak menimbulkan kepemilikan apapun (Zulkarnain dan Sumarsono, 2014). Sekolah sebagai penyedia pelayanan publik diupayakan untuk dapat mempersembahkan pelayanan yang berkualitas secara cepat dan tepat serta prima. Hal ini dikarenakan sebagian besar orangtua memilih sekolah dasar Islam yang dapat melayani kebutuhannya dengan cara yang terbaik, cepat dan tepat, istimewa, dan tentunya sesuai standar sehingga memberikan kepuasan dan kepercayaan tersendiri bagi orangtua atau wali murid.

Dari hasil pengolahan analisis faktor oleh peneliti, dapat ditemukan faktor yang paling dominan terhadap pilihan orangtua dalam menyekolahkan anak pada sekolah dasar berbasis Islam di Kota Malang adalah faktor religi atau agama. Hal ini dikarenakan faktor religi mempunyai sumbangan yang tinggi, yakni sebesar 17,597\% terhadap persentase kumulatif variansi. Angka ini terbilang tinggi apabila dibandingkan dengan faktor yang lainnya. Hasil ini didukung oleh Verdiyani (2016) yang meneliti mengenai analisis animo masyarakat dalam memilih sekolah anak di SD Wuluhadeg dan SD IT Assalam serta penelitian Septhevian (2014) yang meneliti mengenai faktor-faktor yang berpengaruh terhadap keputusan orangtua dalam memilih Sekolah Dasar (SD).

Hasil penelitian yang dilakukan oleh Verdiyani diperoleh bahwasanya faktor yang menjadi pertimbangan masyarakat dalam memilih sekolah dasar bagi anak di SD IT Assalam ialah porsi pendidikan agama, keamanan, prestasi sekolah, pendekatan pembelajaran, serta kedisiplinan. Porsi pendidikan agama di SD IT Assalam merupakan alasan utama orangtua dalam memilih sekolah dasar bagi anaknya. Porsi pendidikan agama di SD IT Assalam lebih banyak dari sekolah negeri. Dengan demikian, faktor religi (agama) sama-sama menjadi faktor yang paling dominan yang mempengaruhi pilihan orangtua dalam menyekolahkan anak pada SD berbasis Islam, baik di Yogyakarta selaku lokasi penelitian Verdiyani, maupun di Kota Malang selaku lokasi penelitian peneliti.

Sedangkan dari penelitian Septhevian didapatkan faktor yang berpengaruh pada keputusan orangtua dalam memilih SD negeri atau swasta ialah kualitas pendidik, porsi agama, fasilitas yang diberikan oleh sekolah, biaya yang dipatok oleh sekolah, lingkungan dan keamanan sekolah. Kualitas pendidik yang dalam hal ini merupakan kualitas guru yang mengajar, biaya yang dipatok, dan lingkungan sekolah menjadikan orangtua lebih cenderung memilih sekolah negeri daripada swasta. Di sisi lain, faktor porsi agama, fasilitas yang diberikan, dan keamanan sekolah menjadikan orangtua lebih cenderung memilih sekolah swasta daripada negeri. Selain itu, faktor yang berpengaruh terhadap keputusan orangtua dalam memilih sekolah berbasis agama atau non-agama adalah faktor agama, citra, serta lingkungan sekolah. Faktor agama dan citra sekolah mampu menarik hati orangtua untuk lebih cenderung memilih sekolah berbasis agama. Sedangkan, faktor lingkungan sekolah yang mendorong orangtua untuk lebih cenderung memilih sekolah berbasis non-agama. Dengan demikian, maka hasil penelitian oleh peneliti mengenai faktor religi sebagai faktor yang paling dominan yang mempengaruhi pilihan orangtua dalam menyekolahkan anak pada SD berbasis Islam di Kota Malang berbanding lurus dengan penelitian terdahulu yang dilakukan oleh 
Septhevian. Sebagaimana pernyataan dari Septhevian bahwasanya faktor agama dan citra sekolah dapat menarik hati orangtua untuk lebih cenderung memilih sekolah berbasis agama. Maka faktor agama menjadi faktor yang paling dominan mempengaruhi pilihan orangtua dalam menyekolahkan anak pada SD berbasis agama, yang dalam penelitian ini adalah Agama Islam.

\section{Simpulan}

Berdasarkan hasil penelitian yang telah dilakukan, maka dapat disimpulkan bahwa (1) faktor yang menjadi pilihan orangtua dalam menyekolahkan anak pada SD berbasis Islam di Kota Malang, yaitu: (a) religi; (b) pendidikan karakter; (c) mutu sekolah; (d) pengembangan potensi; dan (e) pelayanan; (2) faktor yang paling dominan dalam pilihan orangtua menyekolahkan anak pada SD berbasis Islam di Kota Malang adalah faktor religi; sedangkan (3) kontribusi masing-masing faktor yang menjadi pilihan orangtua menyekolahkan anak pada SD berbasis Islam di Kota Malang, yaitu: (a) religi memiliki kontribusi sangat tinggi, (b) pendidikan karakter memiliki kontribusi sedang, (c) mutu sekolah memiliki kontribusi tinggi, (d) pengembangan potensi memiliki kontribusi sedang, dan (e) pelayanan memiliki kontribusi sangat tinggi terhadap pilihan orangtua menyekolahkan anak pada SD berbasis Islam di Kota Malang.

\section{Daftar Rujukan}

Arikunto, S. (2006). Prosedur Penelitian: Suatu Pendekatan Praktik. Jakarta: PT Asdi Mahasatya.

Bidang Pembinaan SD Dinas Pendidikan Kota Malang. (2017). Data Jumlah Peserta Didik Tiap Sekolah Tahun 2016/2017. Malang: Dinas Pendidikan Kota Malang.

Hubeis, A. V. S. (2013). Expentancy Theory (Studi Kasus: Pelaksanaan Training Sebagai Media Untuk Mewujudkan Harapan Karyawan di Suatu Perusahaan Jasa).

Hura, L. (2013). Permasalahan-Permasalahan yang Ada di Madrasah Ibtidaiyah, (Online), (http://lalahura.blogspot.com), diakses pada 25 Januari 2018.

Kamus Besar Bahasa Indonesia. (2018). Agama, (Online), (https://kbbi.web.id), diakses pada 25 November 2018.

Kepala Bidang SD Dinas Pendidikan Kabupaten Bekasi. (2015). Pentingnya Pendidikan Dasar (Online), (www.disdik.bekasikab.go.id), diakses pada 9 Januari 2018.

Prihadhi, E. (2004). My Potensi. Jakarta: Elek Media Komputindo.

Qomar, M. (2015). Dimensi Manajemen Pendidikan Islam. Malang: Erlangga.

Revaldi, A. (2010). Memilih Sekolah untuk Anak. Jakarta Timur: Inti Medina.

Sahroni. 6 November 2015. Mengapa Saya Memilih Sekolah Islam Terpadu. Kompas, hlm. 1.

Septhevian, R. (2014). Faktor-Faktor yang Mempengaruhi Keputusan Orangtua Dalam Memilih Sekolah Dasar (SD). Tesis tidak diterbitkan. Yogyakarta: Universitas Atma Jaya Yogyakarta.

Sholiha, F. (2018). Komunikasi Personal.

Sugiyono. (2017). Metode Penelitian Pendidikan (Pendidikan Kuantitatif, Kualitatif, dan R\&D). Bandung: Alfabeta.

Tempo. (2018). Hari Pendidikan, KPAI: 84 Persen Siswa Alami Kekerasan di Sekolah, hlm. 1.

Triatna, C. (2016). Pengembangan Manajemen Sekolah. Bandung: PT Remaja Rosdakarya.

Ulul Albab School. (2016). Memilih Sekolah Negeri Atau Swasta Untuk Anak?, (Online), (www.ululalbabschool.com), diakses pada 25 Januari 2018.

Undang-Undang Republik Indonesia Nomor 23 Tahun 2002 tentang Perlindungan Anak. Komisi Perlindungan Anak Indonesia (Online), (www.kpai.go.id), diakses pada 9 Januari 2018. 
Jurnal Pembelajaran, Bimbingan, dan Pengelolaan Pendidikan, 1(6), 2021, 495-502

Verdiyani, R. (2016). Analisis Animo Masyarakat Dalam Memilih Sekolah Anak di SD Wuluhadeg dan SD IT Assalam. Jurnal Pendidikan Guru Sekolah Dasar, 23(5), 264.

Vitasari, H. N. (2017). Motivasi Orangtua Menyekolahkan Anak di Sekolah Berbasis Islam (Studi Kasus di Desa Singosari Mojosongo Boyolali). Skripsi tidak diterbitkan. Salatiga: FTIK IAIN Salatiga,

Wibowo, A. (2013). Manajemen Pendidikan Karakter di Sekolah (Konsep dan Praktik Implementasi). Yogyakarta: Pustaka Pelajar.

Yakub \& Hisbanarto, V. (2014). Sistem Informasi Manajemen Pendidikan. Yogyakarta: Graha Ilmu.

Zazin, N. (2017). Gerakan Menata Mutu Pendidikan (Teori \& Aplikasi). Yogyakarta: Graha Ilmu.

Zulkarnain, Wildan \& Sumarsono, R. B. (2011). Manajemen Perkantoran Pendidikan. Malang: Fakultas Ilmu Pendidikan Universitas Negeri Malang. 